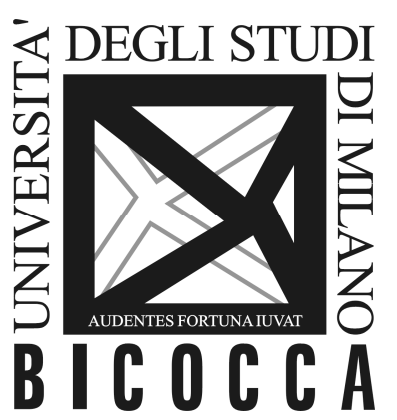

\author{
DEPARTMENT OF ECONOMICS, \\ MANAGEMENT AND STATISTICS \\ UNIVERSITY OF MILAN - BICOCCA
}

DEMS WORKING PAPER SERIES

\title{
Is electoral punishment important for democracy? The role of social capital and religious resources
}

\author{
Ambra Poggi \\ No. 368 - July 2017
}

Dipartimento di Economia, Metodi Quantitativi e Strategie di Impresa Università degli Studi di Milano - Bicocca http://dems.unimib.it/ 


\title{
Is electoral punishment important for democracy? The role of social capital and religious resources
}

\author{
Ambra Poggi \\ University of Milan Bicocca, CISEP and Laboratorio Revelli - Collegio Carlo Alberto \\ Corresponding address: University of Milan Bicocca, \\ U6, piazza Ateneo Nuovo 1, 20126 Milano, Italy \\ ambra.poggi@unimib.it
}

\begin{abstract}
s
Electoral punishment is the main instrument that citizens have to keep government accountable, answerable and accessible to the people they serve. The aim of this paper is to empirically investigate whether individual social resources - social capital and religious resources - may enhance the probability that individuals value electoral punishment important for democracy. We use data from the 2012 European Social Survey Multilevel Data and a multilevel approach. Our findings lend support to the view that social resources matter in determining the importance of electoral punishment, even if the importance of each resource varies across countries. Social capital has a complex effect on the importance of electoral punishment: trust reduces the probability that individuals value electoral punishment, while social participation increases it. Religious resources result negatively correlated with the importance of electoral punishment suggesting that loyalty versus religious values and traditions imply unconditional citizens' support for government. Finally, some religions seem to have a specific role in enhancing the importance of electoral punishment confirming an active role of religious values and authorities in shaping individual political behaviors.
\end{abstract}

Keywords: electoral punishment, religion, social capital, poverty, multi-level models

JEL-codes: C23, D72, 13, O15, A13 


\section{Introduction}

The accountability channel, described as early as 1816 by Jeremy Bentham, emphasizes the ability of citizens to use the electoral mechanism to shape the incentives facing politicians (Bentham,1999; Barro 1973; Ferejohn 1986). In such models, politicians perform well because they fear being turned out of office if they do not. Thus, elections force elected politicians to account for their performance and provide opportunities for challengers to offer citizens alternative policy choices. Moreover, accountability prevents corruption and ensures that public officials remain answerable and accessible to the people they serve. Instead, limited accountability undermine the strength of the incentives mechanism and increases the scope for opportunistic politicians to shirk from their duties or to implement policies far from voters' ideals without electoral consequences (Buchanan 1989). Accountability is, therefore, an important part of the democratic process governing the society (Sen, 1999). Electoral punishment is the main instrument that citizens have to keep government accountable and, therefore, individuals have reasons for valuing it. However, not all individuals equally value electoral punishment. The aim of this paper is to empirically investigate whether individual social resources may impact on the individuals' perceptions about the importance of electoral punishment for democracy.

In this paper, we focus on specific individual social resources that we believe can have an impact on the individual political behavior: social capital and religious resources. Social norms can, for instance, shape the options that an individual consider to be admissible, social contexts can have a crucial impact on the individual judgement, social networks contain the family, friends and professionals from who we seek advice and social participation help us to share information. Thus, social capital (defined as networks, norms, and trust that enable participants to act together more effectively to pursue shared objectives) results relevant in determining individual behaviour and, more in general, for the effective running of modern economic systems (e.g. Coleman,1990; Bourdieu, 1991; Putnam, 2000; Cote and Healy, 2001). Religion has a prominent role in the formation of social capital, but it also provides specific social resources available to individuals and groups through their social connections with a religious community sharing the some norms and values. We refer to these specific social resources as religious resources.

Many studies have provided empirical support for the notion that both social capital and religious resources generally foster prosocial behavior (Galen,2012; Preston et al. , 2010; Purzyckietal., 2016; Shariff, 2015; Benson et at, 1989; Bridges and Moore, 2002) ${ }^{1}$ and the latter is important in shaping the individual political

\footnotetext{
${ }^{1}$ Religious believers donate more money to charities (Bekkers and Schuyt,2008; Bekkers and Wiepking,2011), spend more time doing volunteering work (Wilson,2000), and experience stronger social support from their community than nonbelievers (Koenig et al.,1997). Donahue and Benson (1995) find low to moderate significant correlations between religiousness and altruistic values (the importance of helping others, reducing hunger and poverty, and making the world a better place), and somewhat stronger associations between religiousness and altruistic behavior (participation in charitable activities, donating money or time to charity, and spending time helping others). King and Furrow (2004) conclude that religious participation may promote moral outcomes.
} 
attitudes. Nannicini et al. (2012) find that social capital and prosocial behavior on the part of voters are recognized as important factors in keeping elected officials accountable for their misbehaviors. In facts, voters who share values and beliefs that foster cooperation are more likely to vote based on criteria of social welfare rather than narrow personal interest. These voters tend to punish government that do not perform well. Thus, Nannici et al (2012) find the electoral punishment of political misbehavior is considerably more pronounced in areas with high social capital. According with this argument, we can expect individual social resources (social capital and religious resources) positively impact on the probability that individuals value electoral punishment important for democracy. However, the impact of individual social resources on political behaviors is not so straightforward.

Social capital, as illustrated above, is a complex concept that involve many dimensions including generalized trust and social participation. Generalized trust has been associated with political trust (Levi \& Stoker, 2000; Zmerli and Newton,2016), which implies citizens' support for political institutions such as government and parliament in the face of uncertainty about or vulnerability to the actions of these institutions. According to Easton (1975, p. 447), "the presence of trust would mean that members would feel that their own interests would be attended to, even if the authorities were exposed to little supervision or scrutiny." Instead, skepticism signals a willingness to judge political institutions by their own merits. Democracy requires trust but also presupposes an active and vigilant citizenry with a healthy skepticism of government and a willingness, should the need arise, to suspend trust and assert control over government-at a minimum by replacing the government of the day (Mishler \& Rose, 1997). Thus, this argument suggests that individual trust could negatively impact on the importance of electoral punishment. On the other side, higher social participation may contribute to greater political accountability and responsiveness (Besley and Burgess, 2002). Poorly informed people and lower social participation may increase the scope for fraudulent behaviors and lessen electoral punishment (Ferraz and Finan, 2008; Nannicini et al., 2013). Following this argument, social participation should positively impact on the probability that individuals value electoral punishment important for democracy.

Religion can influence political attitudes and behavior directly shaping views on political issues (through doctrinal affinities) and indirectly implying support for specific policies and regimes (through the organizational support and mobilization of religious authorities and institutions). Religion can thus function both as a source of communal loyalty and shared identity and understandings and as a powerful ideology, a set of normative principles and claims about how the world ought to function (Grzymala-Busse, 2012). Therefore, individuals with strong religious beliefs and connections with their religious community (that are individuals developing high levels of religious resources) could support policies and parties, without question whatever politicians claim, if politicians explicitly share the same beliefs, moral and religion traditions (Roemer 1998, 2001, 2005; Akerlof and Kranton 2000; Gill and Lundsgaarde 2004). If this is true, religious 
resources could be negative correlated with the importance of electoral punishment. On the contrary, when the religious values and authorities support electoral punishment, we could find a positive correlation.

In this paper, in order to test whether individual social resources (religious resources and social capital) impact on the importance given by individuals to electoral punishment, we use data from the 2012 European Social Survey Multilevel Data and a multilevel approach. The latter permits to analyze individual-level factors (including religious resources and social capital) that might affect the probability that an individual value electoral punishment important for democracy controlling for country-level factors (e.g. macro-traits and welfare characteristics of the country in which the individual is situated). Note that the latter could also shape the individual perceptions about the importance of electoral punishment. Our findings lend support to the view that social resources matter in determining the importance of electoral punishment, even if the importance of each resource varies across countries. Social capital has a complex effect on the importance of electoral punishment: we observe a negative correlation between trust and the importance of electoral punishment and a positive correlation between social participation and the importance of electoral punishment. Religious resources are negatively correlated with the importance of electoral punishment suggesting that loyalty versus religious values and traditions prevails on an increasing of pro-sociality due to participation in religion communities. Some religions seem to have a specific role in enhancing the importance of electoral punishment confirming an active role of religious values and authorities in shaping individual political behaviors.

Note that our results contribute to the literature offering new important insights on the factors that may enhance the demand of electoral punishment. Interestingly, we highlight that the impact of each factor have a different strength depending on the country institutional background. Thus, policies aimed to reduce corruption and politicians' misbehaviors need to be country specific and need to promote the developing of individual social resources in the appropriate way (for example, enhancing social participation) and to search for the cooperation of religion authorities in promoting the importance of electoral punishment.

The paper is structured as following. Section 2 illustrates the methodology we use in our analysis. Section 3 gives information about the data. In section 4, we show our empirical findings. Conclusions are made in Section 5 .

\section{The model}

In this section, we present our empirical strategy for social resources (social capital and religious resources) as determinants of the importance of electoral punishment. The key aspects of our modelling are two. First, 
we have the goal of analyzing the determinants of the importance of electoral punishment defined as the importance given by individuals to punish in the election governing parties when they have done a bad job. Second, we wish to control for both individual and country characteristics that impact on the probability of valuing electoral punishment important for democracy. The first point implies consider a binary variable $(\mathrm{Y})$ that takes the value one for individuals valuing electoral punishment important for democracy and zero otherwise. The second aspect is faced by using multilevel modelling technique. Multilevel models explicitly take into account the hierarchical structure of the data, thereby allowing us to analyze - first to measure, then to explain - the proportion of the variability in the importance of electoral punishment, which is attached to each (nested) level. Unlike the fixed effects models, multilevel models make use of the between variance, and are therefore especially useful when this variance is quite high.

\subsection{Random Intercept Model}

We initially estimate a simple two-level intercept model where individuals are clustered in countries (level-1 individuals, level-2 countries). For binary response $E\left(y_{i j}\right)=\pi_{i j}=\operatorname{Pr}\left(y_{i j}=1\right)$, the model can be written as

$$
F^{-1}\left(\pi_{i j}\right)=\beta_{0 j}+\beta_{1 j} R_{i j}+\beta_{2} X_{i j}+e_{i j}
$$

where $\mathrm{F}^{-1}$ is the logit function, $\beta_{0 j}$ is the intercept, $R_{i j}$ represents the vector of social resources of individual $\mathrm{i}$ in country $\mathrm{j}$, the vector $\mathrm{X}$ includes explanatory variables at individual level and $e_{i j}$ is the usual error term (assumed to have a mean of zero and a variance to be estimated). The subscript $\mathrm{j}$ is for the countries $(\mathrm{j}=1 \ldots \mathrm{J}$ ) and the subscript $\mathrm{i}$ is for individuals $\left(\mathrm{i}=1 \ldots \mathrm{n}_{\mathrm{j}}\right)$. In this model, we assume that each country has a different intercept coefficient. Since the latter is a random variables that vary across the countries, it is often referred to as random coefficient. In general, a country with a high intercept is predicted to have more individuals valuing electoral punishment than a country with a low value for the intercept. Across a country, the regression coefficient $\beta_{0 j}$ is assumed to have a multivariate normal distribution and its variation is explained by explanatory variables at the country level (Z):

$$
\beta_{0 j}=a_{0}+a_{1} Z_{j}+u_{0 j}
$$

Equation 2 predicts the average probability of considering important electoral punishment in a country by the macro-traits and welfare characteristics of the country. The u-term is the (random) residual error term at country level and it is assumed to have a mean of zero and to be independent from the residual error at the individual level.

Our model with individual-level and country-level explanatory variables can be written as a single complex regression equation by substituting equation 2 into equation 1 : 


$$
F^{-1}\left(\pi_{i j}\right)=a_{0}+\beta_{1} R_{i j}+\beta_{2} X_{i j}+a_{1} Z_{j}+u_{0 j}+e_{i j}
$$

The model can be estimated using maximum likelihood (ML) estimators. The latter estimate the parameters of a model by providing estimated values for the population parameters that maximize the so-called likelihood function: the function that describes the probability of observing the sample data, given the specific values of the parameter estimates.

The arguments for using multilevel models to analyses hierarchical data are well known (Skrondal and RabeHesketh, 2004; Snijders and Bosker, 1999; Goldstein, 1995; Hox, 1995; Di Prete and Forristal, 1994). When units are clustered classical regression analysis are not appropriate since the underlying hypothesis of independence of the observations is violated. In our case, individuals in the same countries tend to be more similar to each other than individuals in different countries. As a result of this dependency, standard errors could be estimated with a downward bias and, hence, inferences about the effects of the covariates are not corrects conducing to many spurious significant results (Hox, 1995). A simple solution could be that of using robust methods to estimate standard errors. But, when the multilevel structure is not only a mere nuisance factor but instead an interesting dimension of the analysis, multilevel models are more appropriate (Arpino and Aassve, 2007).

The amount of dependence can be expressed as a correlation coefficient: the intra-class correlation coefficient (ICC). It represents the proportion of variance in the outcome variable that is explained by the grouping structure of the hierarchical model. It is calculated as a ratio of group level error variance over the total error variance:

$$
I C C=\frac{\sigma_{u}^{2}}{\sigma_{u}^{2}+\sigma_{e}^{2}}
$$

where $\sigma_{u}^{2}$ is the variance of the level-2 residuals and $\sigma_{e}^{2}$ is the variance of the level-1 residuals. In other words, the ICC reports on the amount of variation unexplained by any predictors in the model that can be attributed to the grouping variable, as compared to the overall unexplained variance (within and between variance).

\subsection{Random slope model}

We extend our model assuming that each country has both different intercept and slope coefficients. Thus, we can write the regression coefficient $\beta_{0 j}$ as:

$$
\beta_{0 j}=a_{0}+a_{1} Z_{j}+a_{2 j} R_{i j}+u_{0 j}
$$

where $a_{2 j}$ is the vector including the random-slope effects and the u-term is the level-2 random intercept. 
Substituting equation 5 into equation 1, we obtain the following single regression equation that can be estimated using maximum likelihood (ML) estimators:

$$
F^{-1}\left(\pi_{i j}\right)=a_{0}+\beta_{1} R_{i j}+\beta_{2} X_{i j}+a_{1} Z_{j}+a_{2 j} R_{i j}+u_{0 j}+e_{i j}
$$

This model contains random slopes for social resources, which means that we are allowing the slope of our regression equation to vary by country. In other word, we believe that for some countries social resources have large effects on the probability to value electoral punishment important for democracy and for other countries the effects are smaller.

Finally, note that the ICC can be computed (Goldstein et al., 2002), but it will be a function of the social resources $\left(R_{\mathrm{ij}}\right)$. Two strategy are possible: we can compute the ICC for particular sets of social resources values or we can report the ICC at the average of the social resources. We follow the latter strategy.

\section{Data, main variables and descriptive statistics}

\subsection{Data}

We use data from the 2012 European Social Survey (ESS) Multilevel Data. The ESS Multilevel Data is a resource that contains data about individuals (the ESS respondents), regions and countries. The ESS survey data is, thus, the point of departure for this resource. The ESS is an academically driven cross-national survey that has been conducted across Europe since 2001. Every two years, face-to-face interviews are conducted with newly selected, cross-sectional samples. The survey measures the attitudes, beliefs and behavior patterns of diverse populations in more than thirty nations. The main aim of the ESS is to chart stability and change in social structure, conditions and attitudes in Europe and to interpret how Europe social, political and moral fabric is changing.

In this paper data from the sixth ESS round (2012) is used. In this round, a special module about democracy was included. The module focuses on two specific components. First, peoples beliefs and expectations about what a democracy should be and secondly, peoples evaluations of their own democracies. The ESS intends to be representative of the residential population of each participating nation aged 15 years and older, regardless of nationality, citizenship or legal status. Anyone who had been living in the country for at least one year and who had no immediate concrete plans to return to country of origin could be selected as respondent. Strict guidelines were used to obtain a dataset of high methodological and theoretical value. An effective sample size of at least 1,500 respondents in each country (800 for countries with less than 2 million inhabitants) was intended. In 2012, the sample sizes varied between 740 (Island) and 2,881 (Germany). We includes in our sample only individuals aged 20 or 
more and we drop records with missing relevant information. Thus, our sample includes a total of 31425 individuals from 29 countries. Weights are used as appropriated.

The 2012 ESS Multilevel Data contains individual data from the 2012 ESS plus contextual data on countries and region from different sources. The contextual variables (measured at country and/or regional level) are included to shed light upon six different themes: demography and geography, composite measures, economy, health, education and crime. Most contextual variables are collected for more than one year in the period from 1990 to 2011. In our analysis, we use contextual 2011 information about GDP growth, government effectiveness and corruption.

GDP growth is computed from GDP per head calculated as the aggregate of production divided by the population size. The indicators of government effectiveness and corruption are two indicators included in the Worldwide Governance Indicators elaborated by the World Bank. "Government effectiveness" captures perceptions of the quality of public services, the quality of the civil service and the degree of its independence from political pressures, the quality of policy formulation and implementation, and the credibility of the government's commitment to such policies. "Corruption" captures perceptions of the extent to which public power is exercised for private gain, including both petty and grand forms of corruption, as well as "capture" of the state by elites and private interests.

\subsection{Variables measuring the importance of electoral punishment and social resources}

In this study, our main dependent variable derives from answers to a question about the importance of punishing governing parties in elections when they have done a bad job on a 0 to 10 point scale. We dichotomize these answers to 0 "punishment is not important for democracy" and 1 "punishment is important for democracy". In particulars, we consider "punishment important for democracy" only if individuals answer with a score at least of 8.

The independent variables measuring resources draw on seven questions that provide data on religion resources and social capital. About religiousness, individuals answer to two questions: how religious are on a score from 1 to 7 and how often they attend religious services apart from special occasion (e.g. weddings and funerals) on a score from 0 to10. Information about social capital derives from scores that individuals give to the following statements: most people can be trusted or you can't be too careful (0-10); most people try to take advantage of you, or try to be fair (0-10); most of the time people helpful or mostly looking out 
for themselves (0-10); how often socially meet with friends, relatives or colleagues (1-7); take part in social activities compared to others of same age (1-5).

To be useful in our analysis, the information on resources need to be aggregated to form a small number of indicators and we use exploratory factor analysis as a dimension reducing strategy to help produce these indicators. Factor analysis is a statistical data reduction technique used to explain variability among observed random variables in terms of fewer unobserved random variables called factors. In general, factor analysis models the observed variables as linear combinations of the factors, plus normally distributed error terms. The algorithm produces a factor structure matrix representing the correlations between the variables and the factors and is called the factor loading matrix. The interpretation of each factor is marked by high loadings on a certain sub-sample of attributes that give information on a specific kind of unobservable. We also perform an oblique rotation allowing factors to be correlated, which makes it easier to interpret the resulting factors.

The results of our data reduction exercise and identification of co-variates of interest are reported in Table 1. These indicators, together with a set of variables about religion identity, gender, age, education, marital status, presence of children in the household, occupation and income, will be our predictors. The KaiserMeyer-Olkin measure of sampling adequacy (KMO) reports a value of 0.72 indicating that the variables have enough in common to run a factor analysis. We identify 3 factors, which in order of proportion of explained variance are: (i) trust; (ii) religious resources; (iii) social participation. Factors (i) and (iii) highlight different aspects of individual social capital. Together these 3 factors explain $74 \%$ of the total variance. Each factor has a zero mean and unit variance by construction.

Descriptive statistics are in Table 2 . We observe that only the $73.8 \%$ of the sample value electoral punishment important for democracy. The $75 \%$ of the individuals declare a religious identity: the $35 \%$ of the sample is Roman Catholic, the $15 \%$ is Protestant, the $15 \%$ is Eastern Orthodox, the $5 \%$ s Jewish and the $7 \%$ is Islamic. Table 3 gives information about the income level, religious resources and social capital by religion identity. Table 4 gives information about religion identities by country. We observe that Roman Catholic, Eastern Orthodox and Islamic individuals have, on average, higher religious resources than other people have. However, they seem to have, on average, lower social capital (trust and social participation). Finally, note that $70 \%$ of the Islamic individuals in our sample are in the fourth decile of income or below (low income).

\section{Empirical results}

In this section, we provide the main results of our models of the importance of electoral punishment as predicted by social resources. We draw on the original data and the data reduction exercise described in the 
previous section and use them to examine the extent and manner in which religious resources and social capital predict the importance of electoral punishment for democracy.

Table 5 carries a set of multilevel models for the importance of electoral punishment that proceed from baseline by adding interaction effects, controls at country level and allowing for some countries social resources have large effects on the probability to value punishment for democracy. The baseline assumes that both social resources and social capital (trust and social participation) have an impact on the probability to value electoral punishment. Moreover, it includes controls for individual characteristics as religion identities, gender, age, education, living in union, children in the household, economic status (in paid work, student, retired, disable) and income level. In the second variant of the model, we control for some country characteristics (GDP growth, effectiveness and corruption) and a third variant tests the role of poverty in mediating the impact of religion identities on the probability to value electoral punishment. We then test, in a forth variant, whether for some countries social resources have large effects on the probability to value electoral punishment important for democracy and for other countries the effects are smaller. The last specification is the preferred specification on the basis of log-likelihood statistics though estimates appear to be relatively robust across the specifications. Focusing on the ICC, we note that it reduces controlling for country characteristics, however our preferred specification report a $6 \%$ of variation unexplained by any predictors in the model that can be attributed to the grouping variable, as compared to the overall unexplained variance.

Individual religious resources and social capital are important predictors of the importance of electoral punishment as hypothesized and discussed in section 1 (see below). Religion identities also impact on the importance of accountability: Jewish and Eastern Orthodox individuals have higher probabilities to value electoral punishment important for democracy (the estimated coefficients are respectively equal to 2.10 and 0.25). Therefore, these religions seem to encourage accountability directly and/or indirectly by promoting pro-social behaviours more than other religions. This result is in line with the results of Kedem and Cohen (1987) showing that sixth grade children in Jewish schools have significantly higher moral judgment and moral behavior scores than the sixth graders attending other schools.

Low income individuals seem to value less electoral punishment (Model 1), however this result varies across religion identities (Model 2-4). Roman Catholic and Islamic low-income individuals only have lower probabilities to value electoral punishment: the estimated coefficients of the interactions are respectively equal to -0.3 and -0.2 and statistically significant at $1 \%$ level. A possible explanation may be draw on the following observations. First, poor individuals are more likely to rely on religion for comfort (Rees, 2009). In facts, the local place of worship may provide material support for people's basic needs, prayer may offer the individual the experience of social support in situations when material social support is insufficient and 
personal religious beliefs can provide a buffer against adverse life events. ${ }^{2}$ Second, Roman Catholic and Islamic religious authorities have a strong attitude to influence political behaviors asking voters to act according to shared religious beliefs and, therefore, reducing the importance of electoral punishment when there are not electoral alternatives sharing the same beliefs. As results, we should not be surprised that Roman Catholic and Islamic low-income individuals have lower probabilities to value electoral punishment.

Focusing on the remaining controls, we find a correlation between education and the importance of electoral punishment: high education is associated with high probability to value electoral punishment, while low education is associated with low probability to value electoral punishment. We also find a correlation between age and the importance of electoral punishment: older individuals appear to have a higher probability to value electoral punishment. Females appear, an average, to value less electoral punishment. Marriage/cohabitation is positively correlated with the importance of electoral punishment.

Finally, when controls at country levels are included (Model 3-4), we find a negative correlation between the lagged GDP growth and the importance of electoral punishment. We also find a negative correlation between the lagged effectiveness and the importance of electoral punishment, while we find a positive correlation between the lagged level of corruption and the importance of electoral punishment. These results can be explained as follow. Citizens in countries with better macroeconomic conditions (e.g. economic growth and low corruption) and more government effectiveness (e.g. better public services and policies) feel that their own interests are attended and, therefore, authorities need less supervision and punishment mechanisms.

\subsection{Individual social resources as a predictor of the importance of electoral punishment}

Turning now to our findings concerning social resources, the specifications reported in Model 1, Table 5 indicate that social participation is positive related to the probability of valuing important electoral punishment (the estimated coefficient is equal to 0.1 ), while trust is negative related to the importance of electoral punishment (the estimated coefficient is equal to -0.07 ). These social resources operate in the manner that might be expected.

Religious resources is negative related to the importance of electoral punishment: the estimated coefficient is equal to -0.07 and it is statistically significant. This result suggests that loyalty versus religious values and traditions imply unconditional citizens' support for government.

\footnotetext{
${ }^{2}$ For example, when someone is suffering it may console him or her to think that the end of the world is near and that God will bring it to a close and reward the faithful with everlasting joy. Doom and gloom predictions about the trials and tribulations that humanity will face before the apocalypse, prevalent in Christian fundamentalism, may also help some people attribute a higher purpose to their suffering, explaining it as "part of God's ultimate plan" (Rees, 2009).
} 
Adding interaction effects and country control variables (Model 2 and 3, Table 5) confirms our results about the relation between the importance of electoral punishment and social resources: coefficients associated with social resources predictors are relatively robust. In Model 4, Table 5, we allow the impact of social resources varying across countries. We find that the strength of the relationship between social resource and the importance of electoral punishment varies a lot between countries as illustrated by the plotted effects of social resources on the importance of electoral punishment in Figure 1.

Moreover, combing the effect of religion resources and religion identities on the importance of electoral punishment we can have a better picture of the strength of the relationship between religion and the importance of electoral punishment (see Figure 2). For Roman Catholic and Islamic low-income individuals, religious resources and religion identity lead to very low probabilities of value electoral punishment. Instead, for Eastern Orthodox and Jewish individuals, religious resources and religion identity strongly increase the probabilities of value electoral punishment important for democracy. Figure 4 confirms the latter result: predicted marginal probabilities of the importance of electoral punishment are higher for Eastern Orthodox and Jewish individuals.

We can also observe the effects of social capital on the importance of electoral punishment by religion identity. For Jewish individuals, social participation has a very strong impact on the importance given by individuals to electoral punishment. Instead, for Protestants, social capital seems to only weakly matter: social participation only weakly increases the probabilities of value electoral punishment, while trust only weakly decreases the probabilities of valuing electoral punishment. For Islamic individuals, trust has very strong impact in decreasing the probabilities to value electoral punishment.

\subsection{Robustness analysis: the importance of the quality of the media information}

We control for the availability of reliable information to judge the government performance. Individuals are asked whether "in country the media provides reliable information to judge the government performance" on a scale from 0 to 10 . We dichotomize the information creating a dummy equal to one if the score is higher than 6 (reliable information), and zero otherwise. This dummy variable is included among the control. Note that some methodological problems may emerge because we are able to measure only perceptions about the quality of information. This is the reason why the dummy about the quality of information is considered for robustness analysis only. Table 6 confirms that our results are robust. Moreover, we find that the quality of information is positively correlated with the importance of electoral punishment: the estimated coefficient is equal to 0.4 and statistical significant at $1 \%$ level. 


\section{Conclusions}

Our findings lend support to the view that social resources matter in determining the importance of electoral punishment, even if the importance of each resource varies across countries. We find that religious resources are negative correlated to the importance of electoral punishment suggesting that loyalty versus religious values and traditions prevails on an increasing of pro-sociality due to participation in the religion community. Social capital has a complex effect on the importance of electoral punishment. Trust is negative correlated to the importance of electoral punishment suggesting the individuals that trust more the members of their community also seem to trust more the government. Instead, social participation results to be positively correlated to the importance of electoral punishment indicating that social inclusion can enhance pro social behavior and, at the end, leading individuals to ask for more accountability. Some religion seem to have a specific role in enhancing perceptions about the importance of electoral punishment confirming an active role of religious values and authorities in shaping individual political behaviors. 


\section{References}

Akerlof, G.A. and Kranton, R.E. 2000. "Economics and Identity" Quarterly Journal of Economics 65 (3): 715-753

Arpino, B. and Aassve, A. 2007. "A difference in difference multilevel model for the analysis of poverty exit determinants and its policy implications: Evidence from rural Vietnam", ISER Working Paper 2007-10, Colchester: University of Essex

Barro, R. 1973. "The Control of Politicians: An Economic Model", Public Choice 14 (September), 1942

Bekkers, R., \& Wiepking, P. 2011. "A literature review of empirical studies of philanthropy: Eight mechanisms that drive charitable giving", Nonprofit and Voluntary Sector Quarterly,40, 924973

Bekkers, R., and Schuyt, T. 2008. "And who is your neighbor? Explaining denominational differences in charitable giving and volunteering in the Netherlands", Review of Religious Research ,50,74-96.

Benson, P.L.., Donahue, M.J and Erickson, J.A. (1989) "Adolescence and religion: A review of the literature from 1970 to 1986", Research in the Social Scientific Study of Religion, 1,153-181

Bentham, J. 1999. "Political Tactics", in "The Collected Works of Jeremy Bentham", ed.by C. B. Michael James, and C. Pease-Watkin. Oxford: Clarendon Press

Bourdieu, P. 1991. "The forms of capital. In: Richardson J, editor", Handbook of theory and research for the sociology of education, New York: Greenwood; 1991. pp. 241-258

Bridges, L.J. and K.A. Moore (2002) "Religion and Spirituality in Childhood and Adolescence", Child Trends

Di Prete T.A. and Forristal J. D. 1994. "Multilevel Models: Methods and Substance", Annual Review of Sociology, Vol.20, pp.331-357

Donahue, M.J., and Benson, P.L. 1995. "Religion and the well-being of adolescents", Journal of Social Issues, 51, 145-160

Easton, D. 1975. "A re-assessment of the concept of political support", British Journal of Political Science, 5(4), 435-457

Ferejohn J. 1986. "Public Choice", vol. 50, issue 1, 5-25.

Ferraz, C. and F. Finan 2008. "Exposing corrupt politicians: the effects of Brazils publicly released audits on electoral outcomes", Quarterly Journal of Economics, 123: 703745

Galen, L. W. 2012. "Does religious belief promote prosociality? A critical examination", Psychological Bulletin, 138, 876-906.

Gill, A. and Lundsgaarde, E. 2004. "State Welfare Spending and Religiosity." Rationality and Society 16 (4): 399-436

Goldstein H. 1995. "Multilevel Statistical Models", Edward Arnold, London

Goldstein, H., Browne W. and J. Rasbash 2002. "Partitioning variation in multilevel models", Understanding Statistics, Volume 1, 2002 - Issue 4, pp.223-231 
Grzymala-Busse, A. 2012. "Why Comparative Politics Should Take Religion (More) Seriously", Annu. Rev. Polit. Sci. 2012. 15:421-42

Hox J.J. 1995. "Applied Multilevel Analysis". Amsterdam: TT- Publikaties

Kedem, P., and Cohen, D.W. 1987. "The effects of religious education on moral judgment", Journal of Psychology and Judaism, 11, 4-14

King,P .E and Furrow, J.L. 2004. "Developmental resources, moral behaviors, and faith communities: Adolescent religiousness and social capital", Developmental Psychology, Vol 40(5), Sep 2004, 703-713

Koenig, H. G., Hays, J. C., George, L. K., Blazer, D. G., Larson, D. B., and Landerman, L. R. 1997. "Modeling the cross-sectional relationships between religion, physical health, social support, and depressive symptoms", American Journal of Geriatric Psychiatry, 5, 131-144

Lazarsfeld, P.F, Berelson, B R, and Gaudet, H. 1944. "The People's Choice", New York: Columbia University Press.

Levi, M., and Stoker, L. 2000. "Political Trust and Trustworthiness", Annual Review of Political Science, $3,475-507$

Mishler, W., and Rose, R. 1997. "Trust, distrust and skepticism: Popular evaluations of civil and political institutions in post-communist societies", The Journal of Politics, 59(2), 418-451

Nannicini, T., Stella, A., Tabellini, G. and U. Troiano 2013. "Social Capital and Political Accountability", American Economic Journal: Economic Policy, vol. 5, no. 2, May 2013

Norenzayan, A. 2013. "Big gods: How religion transformed cooperation and con?ict", Princeton, NJ: Princeton University Press.

Norenzayan, A. and Gervais, W. M. 2013. "The origins of religious disbelief", Trends in Cognitive Science 17:20-25

Nussbaum, M. 2010. "Not for Profit: Why Democracy Needs the Humanities." Princeton: Princeton University Press.

Preston, J. L., Ritter, R. S., and Ivan Hernandez, J. 2010. "Principles of religious prosociality: A review and reformulation", Social and Personality Psychology Compass,4, 574-590

Purzycki, B. G. and McNamara, R. A. 2016. "An ecological theory of gods minds", in "Advances in religion, cognitive science, and experimental philosophy", ed. H. DeCruz \& R. Nichols. Bloomsbury

Putnam, R.D. 2000. "Bowling alone: The collapse and revival of American community". New York: Simon and Schuster

Rees, T. 2009. "Is Personal Insecurity a Cause of Cross-National Differences in the Intensity of Religious Belief?" Journal of Religion and Society (Vol 11).

Roemer, J.E. 1998. "Why the poor do not expropriate the rich: an old argument in new garb." Journal of Public Economics 70 (3): 399-424.

Roemer, J.E. 2001. "Political competition". Cambridge: Harvard University Press.

Roemer, J.E. 2005. "Distribution and politics: a brief history and prospect." Social Choice \& Welfare 25: $507-52$

Sen, A. 1999. "Democracy as a Universal Value" Journal of Democracy 10.3 (1999) 3-17 
Shariff, A. F. 2015. "Does religion increase moral behavior?", Current Opinion in Psychology, 6, 108113.

Skrondal, A. and Rabe-Hesketh, S. 2004 "Generalized Latent Variable Modelling: Multilevel, Longitudinal and Structural Equation Models", Boca Raton, FL: Chapman \& Hall/CRC

Snijders T.A.B. and Bosker R. J. 1999 "Multilevel Analysis. An Introduction to Basic and Advanced Multilevel Modelling", London: Sage

Wilson, D. S. 2005. "Testing major evolutionary hypotheses about religion with a random sample", Human Nature: An Interdisciplinary Biosocial Perspective, 16, 382-409

Zmerli, S., and Newton, K. 2016. "Objects of political and social trust: Scales and hierarchies", in S. Zmerli \& T. W. G. van der Meer (Eds.), Handbook on political trust. Chelton, U.K.: Edward Elgar Publishing 
Figure 1: Effect of social resources on the importance of electoral punishment by country (estimated coefficients)

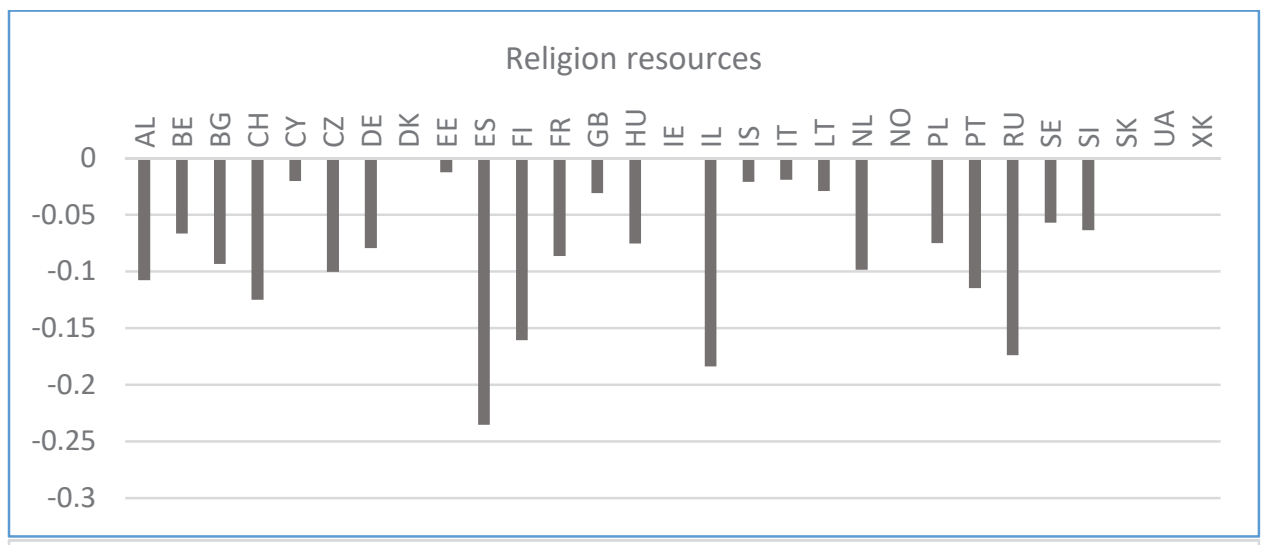

Trust

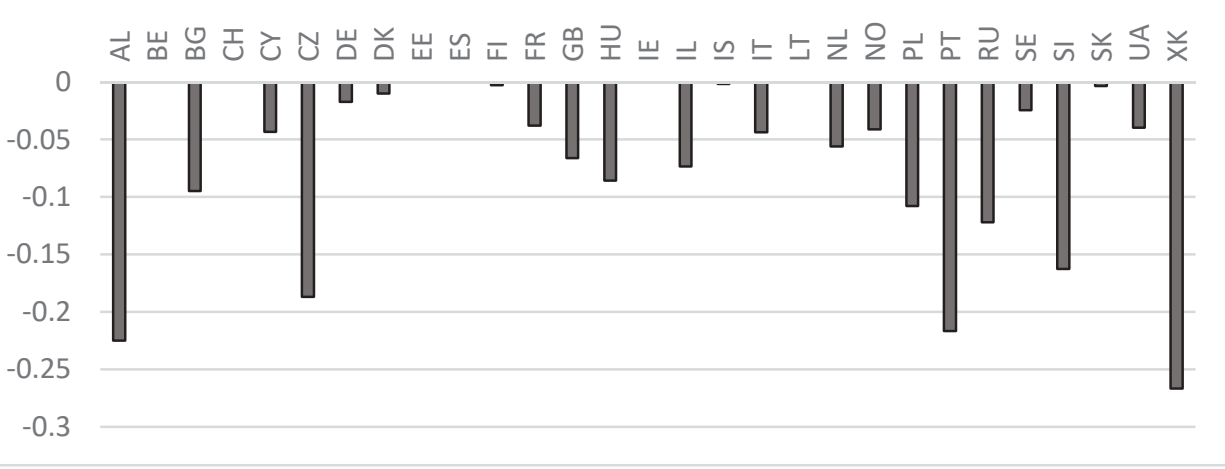

Social participation

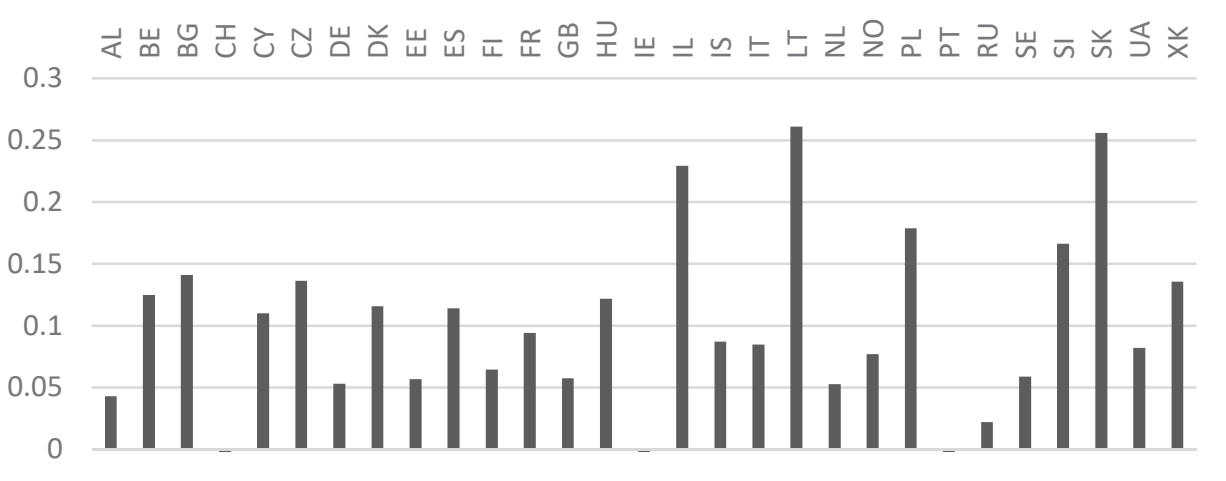


Figure 2: Effect of religion resources and religion identities on the importance of electoral punishment by religion identity (estimated coefficients)

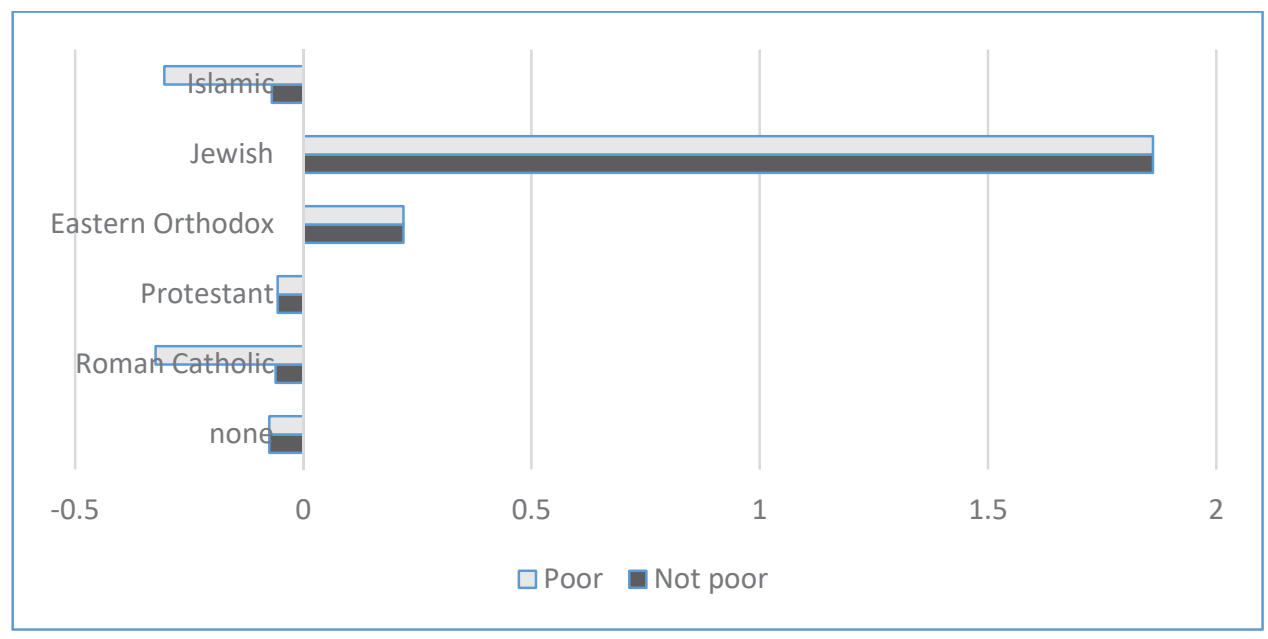

Note: coefficients not statistically significant are considered equal to zero

Figure 3: Effect of social capital on the importance of value electoral punishment by religion identity (estimated coefficients)

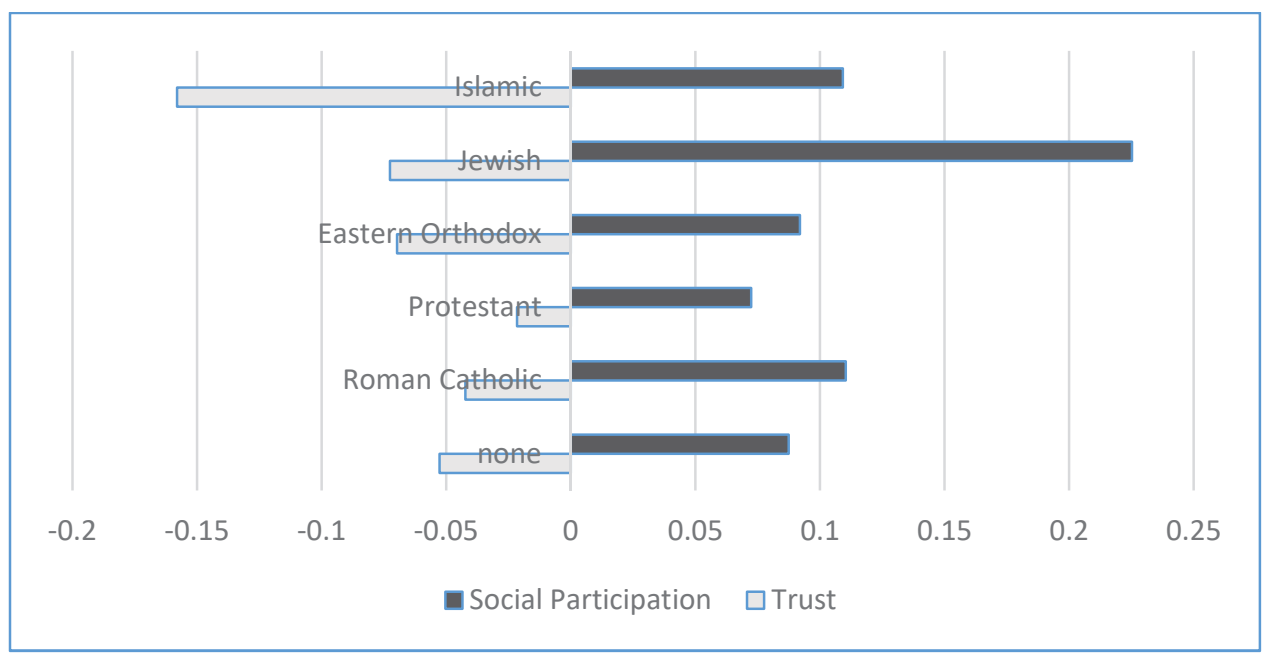

Figure 4: Predicted marginal probabilities over time by religion identity

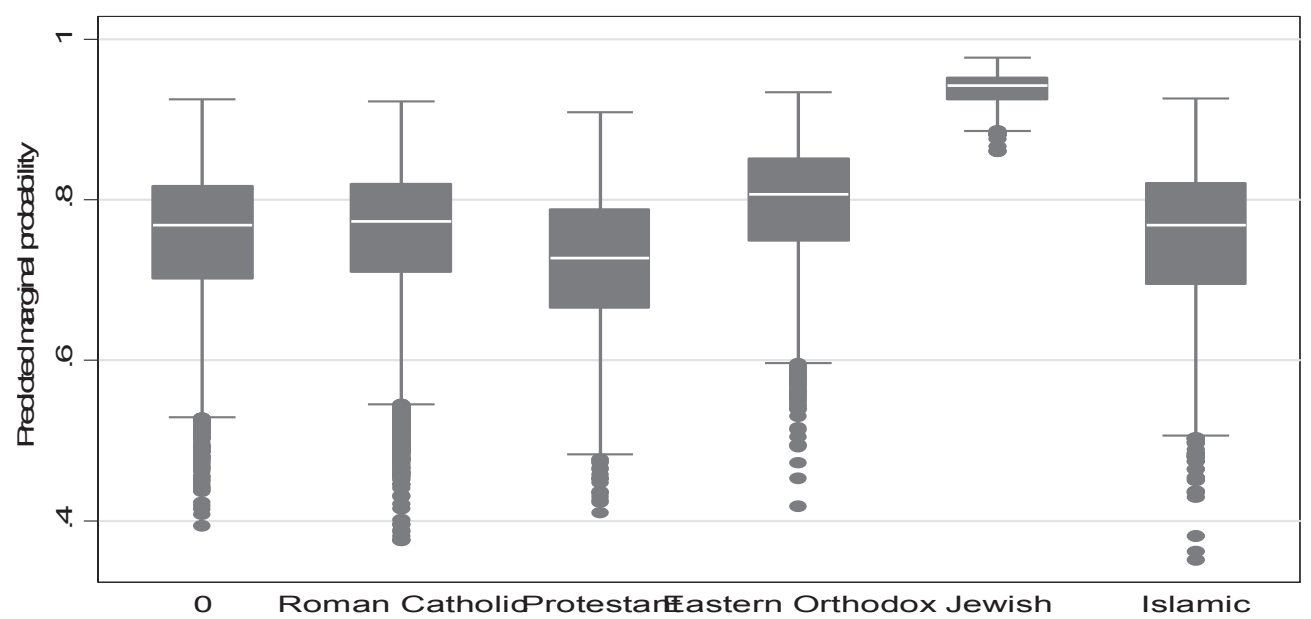


Table 1. Factor analysis

\begin{tabular}{|c|c|c|c|}
\hline Variable & Trust & $\begin{array}{l}\text { Religious } \\
\text { resources } \\
\end{array}$ & $\begin{array}{c}\text { Social } \\
\text { participation }\end{array}$ \\
\hline Most people can be trusted or you can't be too careful $(0-10)$ & 0.841 & & \\
\hline Most people try to take advantage of you, or try to be fair (0-10) & 0.845 & & \\
\hline Most of the time people helpful or mostly looking out for themselves (0-10) & 0.818 & & \\
\hline How often socially meet with friends, relatives or colleagues (1-7) & & & 0.828 \\
\hline Take part in social activities compared to others of same age (1-5) & & & 0.817 \\
\hline How often attend religious services apart from special occasions (1-7) & & 0.909 & \\
\hline How religious are you $(0-10)$ & & 0.908 & \\
\hline Proportion explained & 0.304 & 0.237 & 0.201 \\
\hline Kaiser-Meyer-Olkin measure of sampling adequacy & & & 0.7198 \\
\hline
\end{tabular}

Blanks represent abs(loading)<.4; oblique rotation.

\section{Table 2. Descriptive statistics}

\begin{tabular}{|c|c|c|c|}
\hline \multicolumn{2}{|l|}{ Variable } & \multicolumn{2}{|l|}{ Variable } \\
\hline electoral punishment is important & $73.8 \%$ & In paid work & $49.5 \%$ \\
\hline Low income (<= 4th decile) & $47.5 \%$ & Student & $3.9 \%$ \\
\hline & & Retired & $25.3 \%$ \\
\hline Female & $54.2 \%$ & & \\
\hline Age (average) & 50.2 & Religion is & \\
\hline Living in union & $62.9 \%$ & Roman Catholic & $34.8 \%$ \\
\hline Children in the household & $41.2 \%$ & Protestant & $14.5 \%$ \\
\hline Disable & $2.4 \%$ & Eastern Orthodox & $14.6 \%$ \\
\hline Low education & $24.5 \%$ & Jewish & $4.7 \%$ \\
\hline Medium education & $44.1 \%$ & Islamic & $6.6 \%$ \\
\hline High education & $31.4 \%$ & None & $24.8 \%$ \\
\hline
\end{tabular}

Table 3. Social resources by religion identities

\begin{tabular}{|c|c|c|c|c|}
\hline Religion identity & $\begin{array}{c}\text { Low income } \\
(\%)\end{array}$ & $\begin{array}{c}\text { Religious } \\
\text { resources } \\
\text { (mean) }\end{array}$ & $\begin{array}{l}\text { Trust } \\
\text { (mean) }\end{array}$ & $\begin{array}{c}\text { Social } \\
\text { participation } \\
\text { (mean) }\end{array}$ \\
\hline None & $51.3 \%$ & -1.173 & 0.091 & 0.080 \\
\hline Roman Catholic & $37.9 \%$ & 0.486 & -0.065 & -0.041 \\
\hline Protestant & $53.2 \%$ & 0.189 & 0.566 & 0.187 \\
\hline Eastern Orthodox & $42.0 \%$ & 0.328 & -0.418 & -0.096 \\
\hline Jewish & $70.9 \%$ & 0.136 & 0.081 & 0.110 \\
\hline Islamic & $39.5 \%$ & 0.548 & -0.346 & -0.079 \\
\hline Min & & -1.548 & -2.555 & -2.490 \\
\hline Max & & 2.514 & 2.504 & 2.383 \\
\hline
\end{tabular}

Note: religious resources, trust and social participation have zero mean by construction 
Table 4. Religion identities by Country

\begin{tabular}{|c|c|c|c|c|c|c|}
\hline Country & $\begin{array}{l}\text { Roman } \\
\text { Catholic }\end{array}$ & Protestant & $\begin{array}{l}\text { Eastern } \\
\text { Orthodox }\end{array}$ & Jewish & Islamic & None \\
\hline $\mathrm{AL}$ & $8.3 \%$ & $0.1 \%$ & $11.6 \%$ & $0.0 \%$ & $67.6 \%$ & $12.4 \%$ \\
\hline BE & $41.3 \%$ & $1.3 \%$ & $1.2 \%$ & $0.2 \%$ & $8.1 \%$ & $48.0 \%$ \\
\hline BG & $0.4 \%$ & $1.0 \%$ & $73.3 \%$ & $0.0 \%$ & $15.8 \%$ & $9.5 \%$ \\
\hline $\mathrm{CH}$ & $38.3 \%$ & $32.0 \%$ & $1.8 \%$ & $0.3 \%$ & $5.1 \%$ & $22.5 \%$ \\
\hline $\mathrm{CY}$ & $0.5 \%$ & $0.3 \%$ & $97.7 \%$ & $0.0 \%$ & $1.0 \%$ & $0.5 \%$ \\
\hline$C Z$ & $23.8 \%$ & $1.3 \%$ & $0.1 \%$ & $0.2 \%$ & $0.2 \%$ & $74.3 \%$ \\
\hline DE & $32.6 \%$ & $35.2 \%$ & $1.4 \%$ & $0.1 \%$ & $3.4 \%$ & $27.2 \%$ \\
\hline DK & $1.3 \%$ & $66.0 \%$ & $0.7 \%$ & $0.1 \%$ & $3.3 \%$ & $28.7 \%$ \\
\hline $\mathrm{EE}$ & $1.3 \%$ & $10.5 \%$ & $34.1 \%$ & $0.1 \%$ & $0.4 \%$ & $53.5 \%$ \\
\hline ES & $67.1 \%$ & $1.1 \%$ & $1.2 \%$ & $0.0 \%$ & $1.7 \%$ & $28.8 \%$ \\
\hline $\mathrm{FI}$ & $0.4 \%$ & $70.0 \%$ & $1.7 \%$ & $0.1 \%$ & $0.4 \%$ & $27.4 \%$ \\
\hline FR & $47.4 \%$ & $2.4 \%$ & $0.3 \%$ & $0.9 \%$ & $5.9 \%$ & $43.1 \%$ \\
\hline GB & $13.9 \%$ & $38.2 \%$ & $0.3 \%$ & $0.5 \%$ & $5.4 \%$ & $41.7 \%$ \\
\hline $\mathrm{HU}$ & $46.7 \%$ & $16.0 \%$ & $0.0 \%$ & $0.1 \%$ & $0.0 \%$ & $37.3 \%$ \\
\hline IE & $83.4 \%$ & $3.6 \%$ & $0.7 \%$ & $0.0 \%$ & $0.9 \%$ & $11.4 \%$ \\
\hline IL & $2.0 \%$ & $0.1 \%$ & $1.5 \%$ & $79.5 \%$ & $16.3 \%$ & $0.6 \%$ \\
\hline IS & $1.2 \%$ & $66.1 \%$ & $0.2 \%$ & $0.0 \%$ & $0.2 \%$ & $32.2 \%$ \\
\hline IT & $80.5 \%$ & $0.3 \%$ & $1.0 \%$ & $0.5 \%$ & $2.5 \%$ & $15.1 \%$ \\
\hline LT & $87.3 \%$ & $0.4 \%$ & $5.0 \%$ & $0.1 \%$ & $0.0 \%$ & $7.2 \%$ \\
\hline $\mathrm{NL}$ & $20.2 \%$ & $20.2 \%$ & $0.4 \%$ & $0.0 \%$ & $2.5 \%$ & $56.6 \%$ \\
\hline NO & $3.3 \%$ & $60.5 \%$ & $0.8 \%$ & $0.2 \%$ & $2.4 \%$ & $32.8 \%$ \\
\hline PL & $94.4 \%$ & $0.4 \%$ & $0.3 \%$ & $0.0 \%$ & $0.0 \%$ & $4.9 \%$ \\
\hline PT & $86.7 \%$ & $0.3 \%$ & $0.2 \%$ & $0.0 \%$ & $0.2 \%$ & $12.6 \%$ \\
\hline $\mathrm{RU}$ & $0.2 \%$ & $0.9 \%$ & $59.6 \%$ & $0.1 \%$ & $9.7 \%$ & $29.5 \%$ \\
\hline SE & $2.1 \%$ & $43.1 \%$ & $1.6 \%$ & $0.0 \%$ & $5.6 \%$ & $47.8 \%$ \\
\hline SI & $62.4 \%$ & $0.5 \%$ & $2.3 \%$ & $0.0 \%$ & $1.5 \%$ & $33.4 \%$ \\
\hline SK & $74.6 \%$ & $8.0 \%$ & $0.8 \%$ & $0.0 \%$ & $0.0 \%$ & $16.6 \%$ \\
\hline UA & $10.4 \%$ & $1.5 \%$ & $75.8 \%$ & $0.2 \%$ & $0.5 \%$ & $11.5 \%$ \\
\hline XK & $4.5 \%$ & $0.1 \%$ & $3.7 \%$ & $0.0 \%$ & $91.1 \%$ & $0.6 \%$ \\
\hline
\end{tabular}


Table 5. Estimates of the multilevel random intercept (RI) and random slope (RS) models

\begin{tabular}{|c|c|c|c|c|c|c|c|c|c|c|c|c|}
\hline \multirow{2}{*}{$\begin{array}{l}\text { Dependent variable is } \\
\text { electoral punishment } \\
\text { (important for democracy) } \\
\text { Religion resources }\end{array}$} & \multicolumn{3}{|c|}{ Model - RI } & \multicolumn{3}{|c|}{ Model 2 - RI } & \multicolumn{3}{|c|}{ Model 3- RI } & \multicolumn{3}{|c|}{ Model 4- RS } \\
\hline & -0.074 & $* * *$ & 0.021 & -0.075 & $* * *$ & 0.021 & -0.072 & $* * *$ & 0.021 & -0.064 & $* * *$ & 0.018 \\
\hline Trust & -0.062 & $* * *$ & 0.016 & -0.061 & $* * *$ & 0.016 & -0.061 & $* * *$ & 0.016 & -0.059 & $* * *$ & 0.017 \\
\hline Social participation & 0.108 & $* * *$ & 0.015 & 0.107 & $* * *$ & 0.015 & 0.106 & $* * *$ & 0.015 & 0.100 & $* * *$ & 0.024 \\
\hline Roman Catholic & -0.013 & & 0.055 & -0.018 & & 0.054 & 0.102 & & 0.063 & 0.090 & & 0.066 \\
\hline Protestant & -0.012 & & 0.056 & -0.007 & & 0.056 & 0.011 & & 0.066 & -0.001 & & 0.068 \\
\hline Eastern Orthodox & 0.252 & $* * *$ & 0.076 & 0.255 & $* * *$ & 0.076 & 0.277 & $* * *$ & 0.088 & 0.285 & $* * *$ & 0.091 \\
\hline Jewish & 2.101 & $* * *$ & 0.166 & 2.065 & $* * *$ & 0.166 & 2.067 & $* * *$ & 0.179 & 2.042 & $* * *$ & 0.185 \\
\hline Islamic & 0.068 & & 0.088 & 0.056 & & 0.088 & 0.171 & & 0.119 & 0.197 & & 0.122 \\
\hline Roman Catholic*low income & & & & & & & -0.272 & $* * *$ & 0.075 & -0.263 & $* * *$ & 0.076 \\
\hline Protestant*low income & & & & & & & -0.050 & & 0.089 & -0.057 & & 0.090 \\
\hline Eastern Orthodox*low income & & & & & & & -0.082 & & 0.100 & -0.103 & & 0.101 \\
\hline Jewish*low income & & & & & & & -0.060 & & 0.162 & 0.022 & & 0.166 \\
\hline Islamic*low income & & & & & & & -0.238 & $*$ & 0.134 & -0.236 & $*$ & 0.135 \\
\hline female & -0.140 & $* * *$ & 0.030 & -0.140 & $* * *$ & 0.030 & -0.140 & $* * *$ & 0.030 & -0.146 & $* * *$ & 0.030 \\
\hline Age & 0.051 & $* * *$ & 0.006 & 0.051 & $* * *$ & 0.006 & 0.051 & $* * *$ & 0.006 & 0.051 & $* * *$ & 0.006 \\
\hline age squared & $-4 \mathrm{E}-04$ & $* * *$ & $6 \mathrm{E}-05$ & $-4 \mathrm{E}-04$ & $* * *$ & $6 \mathrm{E}-05$ & $-4 \mathrm{E}-04$ & $* * *$ & $6 \mathrm{E}-05$ & $-4 \mathrm{E}-04$ & $* * *$ & $6 \mathrm{E}-05$ \\
\hline Low education & -0.370 & $* * *$ & 0.040 & -0.372 & $* * *$ & 0.040 & -0.365 & $* * *$ & 0.040 & -0.359 & $* * *$ & 0.041 \\
\hline High education & 0.113 & $* * *$ & 0.035 & 0.114 & $* * *$ & 0.035 & 0.114 & $* * *$ & 0.035 & 0.111 & $* * *$ & 0.035 \\
\hline Living in union & 0.063 & $* *$ & 0.034 & 0.063 & $* *$ & 0.034 & 0.068 & $* *$ & 0.034 & 0.065 & $*$ & 0.034 \\
\hline children in the household & 0.019 & & 0.034 & 0.018 & & 0.034 & 0.016 & & 0.034 & 0.015 & & 0.034 \\
\hline low income ( $<=4$ th decile) & -0.089 & $* * *$ & 0.034 & -0.091 & $* * *$ & 0.034 & 0.034 & & 0.058 & 0.038 & & 0.059 \\
\hline In paid work & -0.102 & $* *$ & 0.042 & -0.100 & $* *$ & 0.042 & -0.098 & $* *$ & 0.043 & -0.103 & $* *$ & 0.043 \\
\hline Student & -0.016 & & 0.085 & -0.015 & & 0.085 & -0.021 & & 0.085 & -0.026 & & 0.086 \\
\hline Disable & 0.028 & & 0.095 & 0.030 & & 0.095 & 0.023 & & 0.095 & 0.024 & & 0.096 \\
\hline Retired & -0.002 & & 0.060 & 0.000 & & 0.060 & 0.002 & & 0.060 & 0.002 & & 0.060 \\
\hline gdp growth (2011) & & & & -6.083 & $* * *$ & 1.706 & -6.134 & $* * *$ & 1.694 & -6.027 & $* * *$ & 1.709 \\
\hline effectiveness (2011) & & & & -1.231 & $* * *$ & 0.408 & -1.238 & $* * *$ & 0.405 & -1.174 & $* * *$ & 0.410 \\
\hline corrupution (2011) & & & & 0.710 & $* *$ & 0.316 & 0.713 & $* *$ & 0.314 & 0.682 & $* *$ & 0.317 \\
\hline Constant & 1.150 & $* * *$ & 0.378 & 1.138 & $* * *$ & 0.339 & 1.096 & $* * *$ & 0.337 & 1.046 & $* * *$ & 0.340 \\
\hline sd(constant) & 0.587 & $* * *$ & 0.080 & 0.451 & $* * *$ & 0.063 & 0.447 & $* * *$ & 0.062 & 0.449 & $* * *$ & 0.063 \\
\hline sd(trust) & & & & & & & & & & 0.111 & $* * *$ & 0.024 \\
\hline sd(social participation) & & & & & & & & & & 0.094 & $* * *$ & 0.021 \\
\hline sd(religion resources) & & & & & & & & & & 0.095 & $* * *$ & 0.023 \\
\hline ICC & 0.095 & $* * *$ & 0.023 & 0.058 & $* * *$ & 0.015 & 0.057 & $* * *$ & 0.015 & 0.058 & $* * *$ & 0.015 \\
\hline Individuals & 30070 & & & 30,070 & & & 30,070 & & & 30,070 & & \\
\hline Countries & 29 & & & 29 & & & 29 & & & 29 & & \\
\hline Log likelihood & -15538.1 & & & -15530.8 & & & -15522.7 & & & -15500.1 & & \\
\hline
\end{tabular}


Table 5. Estimates controlling for the reliability of the media information

\begin{tabular}{|c|c|c|c|c|c|c|}
\hline \multirow{2}{*}{$\begin{array}{l}\text { Dependent variable is } \\
\text { accountability (important for democracy) }\end{array}$} & \multicolumn{3}{|c|}{ Model 3a } & \multicolumn{3}{|c|}{ Model 4a } \\
\hline & Coef & & SE & Coef & & SE \\
\hline Religious resources & -0.076 & $* * *$ & 0.021 & -0.068 & $* * *$ & 0.022 \\
\hline Trust & -0.082 & $* * *$ & 0.016 & -0.082 & $* * *$ & 0.026 \\
\hline Social participation & 0.109 & $* * *$ & 0.015 & 0.103 & $* * *$ & 0.024 \\
\hline Roman Catholic & 0.100 & & 0.064 & 0.086 & & 0.066 \\
\hline Protestant & 0.015 & & 0.066 & 0.001 & & 0.069 \\
\hline Eastern Orthodox & 0.292 & $* * *$ & 0.088 & 0.298 & $* * *$ & 0.092 \\
\hline Jewish & 2.068 & $* * *$ & 0.180 & 2.031 & $* * *$ & 0.186 \\
\hline Islamic & 0.159 & & 0.119 & 0.180 & & 0.122 \\
\hline Roman Catholic*low income & -0.282 & $* * *$ & 0.075 & -0.269 & $* * *$ & 0.076 \\
\hline Protestant*low income & -0.062 & & 0.090 & -0.067 & & 0.090 \\
\hline Eastern Orthodox*low income & -0.095 & & 0.100 & -0.114 & & 0.101 \\
\hline Jewish*low income & -0.085 & & 0.163 & 0.005 & & 0.167 \\
\hline Islamic*low income & -0.254 & * & 0.135 & -0.248 & $*$ & 0.136 \\
\hline The media provides reliable information to judge the government performance & 0.432 & $* * *$ & 0.030 & 0.431 & $* * *$ & 0.030 \\
\hline female & -0.132 & $* * *$ & 0.030 & -0.138 & $* * *$ & 0.030 \\
\hline age & 0.049 & $* * *$ & 0.006 & 0.049 & $* * *$ & 0.006 \\
\hline age squared & 0.000 & $* * *$ & 0.000 & 0.000 & $* * *$ & 0.000 \\
\hline Low education & -0.378 & $* * *$ & 0.040 & -0.372 & $* * *$ & 0.041 \\
\hline High education & 0.116 & $* * *$ & 0.035 & 0.114 & $* * *$ & 0.035 \\
\hline Living in union & 0.074 & $* *$ & 0.034 & 0.071 & $* *$ & 0.034 \\
\hline children in the household & 0.010 & & 0.034 & 0.009 & & 0.034 \\
\hline low income ( $<=4$ th decile) & 0.049 & & 0.058 & 0.050 & & 0.059 \\
\hline In paid work & -0.090 & $* *$ & 0.043 & -0.094 & $* *$ & 0.043 \\
\hline student & -0.018 & & 0.085 & -0.022 & & 0.086 \\
\hline disable & 0.026 & & 0.095 & 0.026 & & 0.096 \\
\hline retired & 0.001 & & 0.060 & 0.001 & & 0.060 \\
\hline gdp growth (2011) & -6.383 & $* * *$ & 1.693 & -6.267 & $* * *$ & 1.704 \\
\hline effectiveness (2011) & -1.307 & $* * *$ & 0.405 & -1.243 & $* * *$ & 0.409 \\
\hline corrupution (2011) & 0.724 & $* *$ & 0.314 & 0.694 & $* *$ & 0.316 \\
\hline constant & 1.028 & $* * *$ & 0.337 & 0.979 & $* * *$ & 0.339 \\
\hline sd(constant) & 0.447 & $* *$ & 0.063 & 0.448 & $* * *$ & 0.063 \\
\hline sd(trust) & & & & 0.107 & $* * *$ & 0.024 \\
\hline sd(social participation) & & & & 0.093 & $* * *$ & 0.021 \\
\hline sd(religion resources) & & & & 0.096 & $* * *$ & 0.023 \\
\hline ICC & 0.057 & $* *$ & 0.015 & 0.057 & $* * *$ & 0.015 \\
\hline Individuals & 30,070 & & & 30,070 & & \\
\hline Countries & 29 & & & 29 & & \\
\hline Log likelihood & -15416.114 & & & -15394.904 & & \\
\hline
\end{tabular}

Note: the percentage of individuals believing that the media provides reliable information is $46.9 \%$ 